\title{
Uit de koers? Over mythe en werkelijkheid
}

Citation for published version (APA):

Verschoor, W. F. C. (2002). Uit de koers? Over mythe en werkelijkheid. Datawyse. https://doi.org/10.26481/spe.20021018wv

Document status and date:

Published: 18/10/2002

DOI:

10.26481/spe.20021018wv

Document Version:

Publisher's PDF, also known as Version of record

\section{Please check the document version of this publication:}

- A submitted manuscript is the version of the article upon submission and before peer-review. There can be important differences between the submitted version and the official published version of record.

People interested in the research are advised to contact the author for the final version of the publication, or visit the DOI to the publisher's website.

- The final author version and the galley proof are versions of the publication after peer review.

- The final published version features the final layout of the paper including the volume, issue and page numbers.

Link to publication

\footnotetext{
General rights rights.

- You may freely distribute the URL identifying the publication in the public portal. please follow below link for the End User Agreement:

www.umlib.nl/taverne-license

Take down policy

If you believe that this document breaches copyright please contact us at:

repository@maastrichtuniversity.nl

providing details and we will investigate your claim.
}

Copyright and moral rights for the publications made accessible in the public portal are retained by the authors and/or other copyright owners and it is a condition of accessing publications that users recognise and abide by the legal requirements associated with these

- Users may download and print one copy of any publication from the public portal for the purpose of private study or research.

- You may not further distribute the material or use it for any profit-making activity or commercial gain

If the publication is distributed under the terms of Article $25 \mathrm{fa}$ of the Dutch Copyright Act, indicated by the "Taverne" license above, 


\section{UIT DE KOERS?}

Over mythe en werkelijkheid 


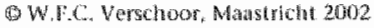

184090927359

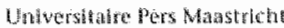

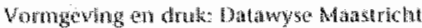




\section{UIT DE KOERS? \\ Over mythe en werkelijkheid}

Inaugurele rede

in verkorte vorm uitgesproken bij de aanvaarding van het ambt wan bijzonder hoogleraar Internationale Financiering zan de Faculteit der Economische Wetenschappen en Bedrijfskunde van de Universiteit Maastricht op wrijdag 18 oktober 2002 door

Dr. W.F.C. Verschoor

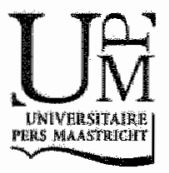


Aan mijn ouders

Wijsheid wordt je niet onderwezen, die moet je zelf ontdekken, na een reis die niemand vaor je kan maken of je kan besparen. Marcel Proust 
Mijnheer de Rector Magnificus,

Zeer gewaardeerdle dames en heren,

\section{AANMONSTEREN}

Wie groots en meeslepend wil leven, kan maar beter geen wetenschapper worden. Althans, dat zou je tenminste denken als je ons zo bezig ziet: voortdurend knoelen met formules en modellen, daarbij de blik voorbij oneindig starend naar een beeldscherm. Of zomaar wat hersengymnastiek op de kleine mat, naarstig op zoek naar de ontbrekende stukjes van weer een zelfgecreèerde puzzel. Het beeld dat vaak opkomt is dat serieuze (economische) wetenschap vooral zichzelf als onderwerp heeft: 'economics for economics, oftewel narcisme in zijn meest zuivere vorm. Deze karikatuur van de afstandelijke wetenschapper in zijn ivoren toren vind ik persoonlijk moeilijk te rijmen met de rijke, veellal minder voorspelbare en dus spannender werkelijkheid van ons bestaan. Zoals voor het eerst werd onderkend door Thomas Kuhn, is wetenschap bovenal mensenwerk. Deze activiteit, waar vanuit een bepaald denkkader nieuwe grenzen worden verkend, is fascinerend en in zekere zin zelfs verslavend. In onze jacht naar nieuwe resultaten en internationale erkenning thebben we in de dagelijkse praktijk intensief contact en afstemming met collega's en studenten, zowel internationaal als lokaal op de faculteit.

Helaas kunnen ook wij ons niet helemaal onttrekken aan de bestaande beeldvorming. Zo blijft bijwoorbeeld de aloude vraag 'if you're so smart, why aren't you rich' ons achtervolgen. In feite relativeert het de pretenties van vele wetenschappers. Dit terwijl het antwoord zo voor de hand ligt; 'rich is boring," althans tot op zekere hoogte. Er moeten dus andere motieven zijn dat de wetenschapper drift in zijn speurtocht naar "bet kennen van de werkelijkheid," ofwel het onzichtbare proberen zichtbaar te maken. In wezen is er maar én ding dat hem drift en in toom houdt: passie. Slechts de verbetenheid die geldjagers vaak kenmerkt, is qua intensiteit vergelijkbaar met de soort passie waaraan je de onderzoeker kunt herkennen. Vanuit pure 
neuwsgiengheid of vanuit een gevoel van verantwoordelijkheid is er sprake van een grote mate van vasthoudendheid, een concentratie op het monomane af, en een toewijding die grenst aan liefde. Het resultaat van dit alles is bij uitstek een menselijke bezigheid die binnen een sociale context plaatsheeft en als zodanig via onderzoek de maatschappli stuurt. Naast het brede maatschappelijk belang, is wetenschap tevens een culturele activiteit waarbinnen de mens op zoek is naar een beter begrip van deze wereld.

Waarom is deze relativering wan het wetenschappelijk bedrijf nu wan belang? Allereerst omdat onze belangrijkste drijfveer, passie, een van de meest kwetsbare eigenschappen is. Passie maakt ons kwetsbaar en in de huidige maatschappij wordt dit verder versterkt door holle opschepperij over alles behalve wetenschappelijke prestaties. Men stort zich liever op de commerciẻle pseudo-passie voor popsterren of tegenwoordig zelfs politici, dan een vlucht naar de hardheid van de wetenschappelijke precisie. Einstein is duidelijk geen popster. Authentieke passie is daarom vaak moeilijk te herkennen en veelal is het raadzaam om de intensiteit van je drijfveren wat te verdoezelen. Daar staat tegenover dat men, wanneer eenmaal de passie als driffveer is onderkend, een nieuwe wereld betreedt die fascineert en inspireert. En het is nu juist deze verwondering die als basis dient voor nader onderzoek. Dat geeft antwoorden die leiden tot meer kennis en meer begrip. Anderzijds leiden de wetenschappelijke antwoorden tot een verdieping van de vragen die we stellen over de wereld om ons heen: "het weten heft het geheim niet op maar verdiept het." Het is mijns inzlens dan ook niet terecht dat de voortgang van de wetenschap enkel is af te meten aan ontdekkingen van nieuwe basisprincipes. Integendeel, juist de verdieping van de vragen die wij stellen over de wereld om ons heen is essentieel.

Vandaag aanvaard ik het ambt van bijzonder hoogleraar Internationale Pinanciering aan de Universiteit Maastricht. Geinspireerd door zowel de vele inzichten en toepassingen die mijn vakgebied te bieden heeft als de ervaringen die ik heb opgedaan in de financiële praktijk, wil ik u vandaag deelgenoot maken van mijn fascinatie voor de turbu. lente wereld wan aandelen, rentewoeten en wisselkoersen. In deze rede zal ik aandacht besteden aan zogenaamde anomalieèn, ofwel 'zwarte 
gaten,' die zo kenmerkend zijn voor het academische domein van de internationale financiering. Haar betekenis voor de wetenschapsbeoefening in het algemeen alsmede de empirische relevantie wan een aantal puzzels en de daaruit voortvloeiende kansen staan daarbij centraal. In dit kader bezien is het belangrijk te benadrukken dat de vele verrassingen en verschijnselen die niet bevredigend kunnen worden verklaard binnen de economie, vaak weer leiden tot nieuwe vragen en theorieën. Tenslotte, zal ik proberen om in een notendop de stand van zaken op te maken wat betreft de uitdagingen in mijn vakgebied anno 2002.

\section{HET ROER KAN NOG ZESMAAL OM}

Het verschijnsel wetenschap, dat eeuwenlang model heeft gestaan voor ons idee van waarheid en vooruitgang, heeft zeer verschillende aspecten. De eerste wetenschappelijke denker die zijn vooruitgangsgeloof overtuigend wist te formuleren is Francis Bacon. Hi] vergelijkt de wetenschap met "een lantaarn die steeds verder schijnend alles aan het licht zall brengen dat het meest verborgen geheim op de wereld is." De normale wetenschap, zoals door Thomas Kuhn in 1962 uiteengezet in zijn beroemde boek "De structuur van wetenschappelijke revoluties,' gaat uit van een verzameling vooronderstellingen of paradigma's die door een wetenschappelijke school wordt gedeeld en niet (meer) ter discussie staan. Tijdens de universitaire opleiding worden studenten en onderzoekers deze paradigma's - wetten, modellen en methoden - aangeleerd en vormen ze als zodanig het kader waarbinnen wetenschappelijke vraagstukken (puzzels) kunnen worden opgelost. Het heersende paradigma ter zake werpt zelf de vragen op. ledere wetenschapper die een wraag beantwoordt, ontdekt in feite een ontbrekend puzzelstukje en woegt het toe aan de bestaande puzzel.

Echter, de gedachte dat wij met het bereiken van zo'n theorie-van-alles 'alles zouden weten' is mijns inziens arrogant en onzinnig. Zo is het altijd mogelijk dat er nieuwe verassingen en verschijnselen zijn waar te nemen die niet bevredigend kunnen worden verklaard 
op basis van het dan geldende paradigma. De onderzoeker vindt dan een puzzelstukje dat niet in zijn puzzel past; bepaalde verschijnselen wijken af van de verwachtingen. Wanneer er nu teveel puzzels onopgelost blipwen, raakt het paradigma in een crisis en kunnen er alternatieve paradigma's boven tafel komen. Blijken die succesvoller, dan betekent dit de ondergang van een oude en de geboorte van een nieuwe school. Er heeft, met andere woorden, een wetenschappelijke revollutie plaats. Grote voorbeelden van zulke revoluties zin de overgang van de aristotelische naar de newtoniaanse mechanica en van de newtoniaanse mechanica naar die van Einstein. Deze owergangen van oude naar nieuwe paradigma's verlopen doorgaans zeer geleidelijk, zodat wetenschappelijke revoluties een lange periode kunnen bestrijken.

Van belang is dat er dus steeds revolutionaire breuken plaatshebben in de wetenschappelijke ontwikkeling, welke kunnen leiden tot plotselinge veranderingen in de perceptie van de werkeli $j k$ heid. De vraag is echter of deze schoksgewijze voortgang van de wetenschap ons nu dichter bi deze (nieuwe) werkelijkheid brengt en bijvoorbeeld niet terugdeinst op onze nadering, zoals de horizon voor de reiziger.' Dagelijks worden nieuwe verschijnselen ontdekt die mogelijkerwijs niet verklaard kunnen worden op basis van de huidige kennis; darnaast zijn er tal van wetenschappelijke vraagstukken waar wij nog diep in het duister tasten. Enkele voorbeelden: Wat is de oorsprong van het heelal? Hoe werken de menselijke hersenen? Of dichter bij huis: Wat zijn de gevolgen van globalisering voor zowel het algemene welvaartsniveau als het (toekomstige) marktrisico waaraan beleggers onderhevig zijn? Vragen te over dus, en meer dan genoeg werk aan de winkel voor de wetenschappers. Ik voel dan ook, met alle respect, mee met Isaac Newton, een van de grootste geleerden ooit, die, bijna drie eeuwen geleden aan het eind van zijn lewen zei: "Ik weet niet wat ik voor de wereld schijnen moge, maas voor mijzelf lijk $1 \mathrm{k}$ slechts een kind geweest te zljn, dat aan liet zeestrand speelt en zich vermakt met nu en dan een gladdere steen of een mooiere schelp te vinden dan gewoon, terwijl de grote Oceaan der wereld onontdekt voor mij lag." 


\section{IN HET VOETSPOOR VAN ADAM SMITH}

Wat verstaan we nu eigelijk onder de economische wetenschap? Om deze vraag te beantwoorden, sluit ik graag aan bij de volgende definitie, ontleend aan Lionel Robbins: "Economie is de wetenschap die het menselijk handelen bestudeert als de relatie tussen gegeven doeleinden en schaarse, alternatief aanwendbare middelen." Het fundament van de economie, waar ons hele gebouw op rust, betreft de theorie van optimale keuzes door rationele mensen, waarbij het paradigma van de economie al sinds de $18^{\mathrm{e}}$ eeuw is verankerd in de beroemde uitspraak van Adam Smith in 1776 over de rol van de slager, de brouwer en de bakker. ${ }^{\text {I }}$ Deze vaak geciteerde witspraak luidt als wolgt: "It is not from the benevolence of the butcher, the brewer, or the baker, that we expect our dimer, but from their regard to their own interest." Met andere woorden: Als de slager, brouwer en bakker werkelijk in ons welzijn waren geïnteresseerd, dan zou onze maaltijd minder smakelijk zijn.

Het is juist deze visie die de ontwikkeling van de economie heeft bepaald. Nog altijd staan in de thans dominante neo-klassieke economische theorie nutsmaximalisatie en winstmaxi-malisatie garant voor een objectieve beoefening van de wetenschap. Voor bijvoorbeeld ethiek, psychologie en sociologie is geen (of nauwelijks) plaats, althans niet binnen de economische theorie. Wie zich, tegen beter weten in, op dergelijke terreinen begeeft, plaats zich volgens de gang. bare opvattingen buiten de economische wetenschap. De vraag, echter, is of daarmee het menselijk handelen in het economisch verkeer afdoende kan worden verklaard. Ik zal hier verderop in deze rede op terugkomen. We weten inmiddels dat de economie als wetenschap vele 'zwarte gaten," ofwel anomalieën, kent; door de theorie en de empirie met elkaar te confronteren, dat wil zeggen daar watr de beste wetenschap wordt bedreven, kunnen dergelijke 'gaten' worden ontdekt. Het begrip anomalie omschrijf ilk als een empirisch resultat dat moellijk is te rationaliseren of wanneer onwarschijnlijke veronderstellingen nodig zijn om het te kunnen verklaren binnen een richtingbepalend paradigma. 
Sociale wetenschappers, en economen in het bijzonder, scheppen veelal hun eigen wereld en laten vervolgens anderen naar buiten kijken of de werkelikheid met hun ideeën overeenkornt. Wanneer we de wereld maar vreend genoeg modelleren, dan liggen de anomalieèn bij wijze van spreken voor het oprapen; het pure streven wan eigenbelang kan vaak de afloop van economische processen niet wolledig verklaren. In zijn uiterste consequentie kan dit streven leiden tot inefficientie, of zelfs tot absurde uitkomsten. Wie bij wijze van spreken door de winkel van de econoom loopt, bekruipt vaak het gevoel dat het een rariteitenkabinet is. We hebben, om met Coase te spreken, "Consumers without humanity, firms without organizations, and even exchange without markets." ${ }^{2}$ Het is mijns inziens dan ook niet meer dan terecht dat economen ervan beschuldigd worden dat ze met name sterk zijn in het beschrijven van "the behavior of incredibly smart people in unbelievably simple situations, ${ }^{\prime \prime}$ terwijl we in feite inzicht nodig hebben in hoe "believably simple people cope with incredibly complex situations."

\section{DE ACTIERADIUS VAN EEN ECONOOM}

In dit kader bezien is het interessant om na te denken over het wereldbeeld van de econoom anno 2002 en in hoeverre het veronderstelde streven naar eigenbelang voldoende richting geeft in ons huidige economisch leven. Waar het mij met name om gaat, is de empirische kwestie: hoe mensen feitelijk handelen en wat dit voor de economische werkelijkheid betekent. Met andere woorden: in hoeverre loopt de huidige econoom tegen de grenzen van zijn veronderstellingen op en welke consequentie heeft dit voor het heersende wereldbeeld?

Binnen de moderne financieringstheorie wordt een vooraanstaande plaats ingenomen door de zogenaamde efficiënte markthypothese. In de laatste veertig jaar is dit een van de meest actieve en spannende wetenschapsvelden in de financiele economie geweest. Achter deze - ogenschijnlijk - wat salie term schuilt een interessante wereld waar alles draatt om efficiente prijsvorming, informatieverwerking, en 
bipassende risiconeutraliteit en rationaliteit. Wat is nu de wetenschappelijke basis van de efficiënte markt hypothese? Het witgangspunt van deze neo-klassieke financieringstheorie is dat beleggers zich volkomen rationeel gedragen en dat de beleggingsmarkt perfect functioneert. In een dergelijke geidealiseerde situatie zal de beleggingsmarkt tevens (informatie) efficiënt zijn. Op een efficiente markt zijn de koersen een "correcte" afspiegeling van alle informatie die voor de prijsvorming van belang kan zijn. Geen enkele belegger zal dan ook in staat zijn de markt te verslaan - dat wil zeggen, iedere belegging levert gemiddeld genomen uitsluitend het rendement dat behoort bij het risico van die belegging.

In de afgelopen decennia zijn vele niewwe concepten en toepassingen ontstaan die alle zijn geẻnt op deze neo-klassieke theorie. Een van de belangrijkste bijdragen betreft de Modeme Portefeuillyetheorie van Markowitz (1952) en het daaruit resulterende prijsvormingsmodel, het zogenaamde Capital Asset Pricing Model (CAPM). In zijn baanbrekende artikel gaat Markowitz ervan uit dat beleggers streven naar een zo hoog mogelijk verwacht portefeuillerendement terwijl ze tegelijkertijd proberen het risico te minimaliseren. Het CAPM wordt onder meer gebruikt om een maatstaf voor het verwachte rendement van andelen te verkrijgen, alsmede om de prestaties van beleggingstondsen te beoordelen.

Ook zijn er vele andere ontwikkelingen waar te nemen die zich hebben gericht op het verklaren en voorspellen van rendementen van financièle activa, zoals methodes om de waarde van een afgeleid financieel instrument te bepalen. Het is dan ook tekenend dat meer dan de helft van de Nobelprijzen voor economie in het afgelopen decennium werden toegekend voor ontdekkingen in het gebied van de portefeuilletheorie en prijsvorming op financiële markten.

Feit is nu dat financieeleconomische modellen kwetsbatr $z$ ijn doordat op basis van een antal veronderstellingen, zoals veel vragers, veel anblieders, volledige informate, risiconeutralleit en perfect werkende kapitaalmarkten, een abstracte redenering wordi opgezet die leidt tot een uitspraak hoe de werkelijkheid in elkaar zou (kunnen) zit * ten. Het gevolg hlervan is dat we soms verschijnselen waarnemen die strijdig zijn met de gangbare theorieèn. Zo heeft de efficiënte markt- 
hypothese voor veel opschudding gezorgd; er blijken in de praktijk rendementsverhoudingen op de beleggingsmarkt te bestaan, die in strijd zijn met het bestaan van marktefficiëntie. Hierdoor zouden zich mogelijkheden kunnen voordoen om extra beleggingsrendement te behalen zonder extra risico te nemen. Zoals reeds eerder betoogd in deze rede, spreken we dan van anomalieën. Het feit dat deze anomalieën bestaan en blijven bestaan, wijst in eerste instantie op een zekere mate van inefficiëntie van de beleggingsmarkt. Deze inefficiëntie kan berusten op imperfecties in de markt en/of op onvolkomen rationaliteit van die beleggers. Zo houdt, bijvoorbeeld, de efficiënte markthypothese geen rekening met de psychologie van de belegger of meer algemeen, met het heersende marktsentiment. Een bekend voorbeeld uit de cognitieve psychologie is het zogenaamde 'overreactie-effect'; mensen hebben de neiging teveel gewicht toe te kennen aan recente gebeurtenissen en te weinig aan reeds eerder bekende informatie. Het gevolg van deze systematische irrationaliteit is dat er op de financiële markten een overreactie-effect in aandelenkoersen plaatsheeft. Andere bekende vormen van systematische irrationaliteit zijn 'short-termism'; beleggers richten hun aandacht meer op de gevolgen van besissingen voor korte termijnwinsten en minder op de consequenties voor de lange termijnwinsten of 'loss-aversion, "wat duidt op de situatie dat aan verwachte verliezen een relatief zwaarder gewicht wordt toegekend dan aan verwachte winsten van gelijke grootte.

Marktsentimenten of andere vormen van systematische irrationaliteit kunnen er dus voor zorgen dat de theorie achter de hypothese niet opgaat. Niettemin kan aan sommige van deze vreemde verschijnselen een rationele verklaring ten grondslag liggen, waarover later in deze rede meer. Ferst echter wil ik enkele fascinerende verschijnselen, die het domein van de internationale financiering karakteriseren, nader bespreken.

\section{MYTHE EN WERKELIJKHEID}

Internationale financiering is bij uitstek een empirisch vak, waarbij wereidwijd veel energie wordt gestoken in het verzamelen en inter- 
preteren van gegevens, die inzicht geven in het gedrag van marktparticipanten op de internationale kapitaalmarkt. Dat daarbil de theorievorming enigszins achterloopt bij de waarneming is geenszins een ongezonde situatie. Dit illustreert slechts het primaat van de empirie en het ontbreken van theoretische vooroordelen. Het is mijns inziens wel wenselijk dat het gat tussen de theorie achter de hypothesen en de empirie kleiner wordt. Ik zal dat in het navolgende proberen te illustreren.

\section{DE VOORSPELFOUT VAN TERMIJNKOERSEN: EEN PUZZEL?}

Zoals gezegd, bestaan er op het terrein van de internationale financiering verschillende onderbelichte of nog niet goed begrepen verschiinselen. Stel dat $u$, als manager van een internationaal opererend Nederlands bedrijf, over een maand de verplichting heeft een miljoen dollar te betalen aan een Amerikaanse leverancier. Op dit moment echter beschikt u over voldoende (bimnenlandse) liquide middelen om aan uw buitenlandse verplichtingen te voldoen. De vraag is nu: wat is de beste strategie, oftewel moet $u$ nu of pas over een maand uw geld omruilen voor Amerikaanse dollars? $U$ besluit te rade te gaan bij een gerenommeerd financieel adviesbureau voor uitsluitsel. Tot uw eigen verbazing wordt u verteld dat het niet (of nauwelijks) uitmaakt waar en wanneer $u$ uw geld uitzet, want, zo is het argument, valutamarkten zijn de meest efficiënte markten ter wereld. Toch weten zij u niet helemaal te overtuigen en bilif er gerede twijfel bestaan. Als een soort van compromis wordt besloten tot een gezamenlijk experiment, waarbij twee alternatieve strategieën worden opgezet. De strategie van de consultant betreft het simpelweg opgooien van munten - de uitkomst van kop of munt bepaalt in dit geval in welke markt zal worden belegd. $U$ volgt een andere, meer opportunistische strategie door te beleggen in die markten met de hoogste rentes.

Na ruim een maand, aan het einde van de proefperiodé, worden de behaalde resultaten met elkaar vergeleken en wat blijkt: de door u gekozen strategie heeft verreweg het hoogste rendement behaald en 
lat de duur betalde consultant aangeslagen achter met zin gestileerde hypotheses over efficient werkende valutamarkten.

Zinn we nu in staat om deze schimbare controverse tussen theorie en praktijk te wsklaren? Onder de veronderstelling dat participanten in de valutamarkt risiconeutral en rationeel zin, makkt het in principe niet uit war we onze transactie angaan - zie het advies van onze financieel consultant. ${ }^{3}$ Immers, het beogde renteverschil tussen een deposito in Amerikaanse dollars en een verder uniek deposito in Euro's in de Nederlandse markt is volgens de gangbare theorie gelijk an de verwachte waardedaling van de dollar ten opzichte van de Euro over de looptijd van de deposito's. Deze wetmatigheid op financièle markten noemen we ongedekte rentepariteit en kan via de volgende regressievergelij king worden getoetst:

$$
S_{4+1}-S_{i}=\alpha+\beta\left(i_{t}-i^{*}\right)+\varepsilon_{t+1}
$$

waar $S_{\mathfrak{f}}$ gellik is aan de spotkoers op tijdstip $t, S_{t+1}$ de spotkoers op tijdstip $t+1$, $i_{t}$ en $i^{*}$, de eigen en buitenlandse rente, en $\varepsilon_{t+1}$ een storingsterm met gemiddelde nul en niet gecorreleerd met het renteverschil. Onder de nulhypothese van ongedekte rentepariteit is a gelijk aan nul en $\beta$ gelifik aan één.

De omvangrijke empirische onderzoeken naar deze prominente wisselkoerstheorie zijn in het algemeen weinig bemoedigend te noemen; voor de belangrijkste valuta's is de waarde van de $\beta$ 's meestal negatief, soms positief, maar nooit groter dan 1. Froot en Thaler (1990) concluderen in hun overzichtsartikel dat over circa 75 gepubliceerde schattingen de $\beta$-coëfficiént een gemiddelde waarde heeft van -0.88 . We kunnen dan ook terecht constateren dat het gemiddeld voordeliger is om te belleggen in de valuta met de hoogste rente; deze extra rente weegt namelijk ruim op tegen het eventuele koersverlies over de looptijd van de belegging. Dit is ook precies in overeenstemming met de door u gehanteerde strategie. Enige terughoudendheid, echter, is hier op zijn plaats; de verklaringskracht van vergelijking (1) is in vele gevallen laag. Ook schijnt de gevonden mate van afwilking van ongedekte rentepariteit gewoelig te zijn voor het onderhavige systeem van wisselkoersen. Met andere woorden: ook uw strategie kan 
gevaar lopen, zodat er zeker niet altijd sprake is van risicoloze "excess" -rendementen.

Het is evident dat er uitgebreide pogingen zijn gedaan om deze schijnbare tegenstelling tussen theorie en empine te verklaren, en war mogelijk te weenleggen. In principe zijn er twee kandidaten orm de systematische voorspelfouten in de prijsvorming van termijncontracten, ofwel het verwerpen van ongedekte rentepariteit, te verklaren. Allereerst is en de mogelijkheid van (tijdsvariêrende) risicopremies; marktparticipanten zijn darn niet indifferent ten opzichte van het aanhouden van een open positie in vreemde valuta en zullen derhalve een risicopremie verlangen voor een dergelijke positie. Daarnaast bestaat de mogelijkheid dat beleggers irrationele verwachtingen hebben ten aanzien van de wisselkoersworming; de verwachte wisselkoersverandering $z$ al dan systematisch afwijken van de werkelijke verandering.

Tijdens mijn promotieonderzoek ben ik zelf werkzaam geweest op dit specifieke terrein van de wisselkoersiteratuur. Middels het gebruik van directe waarnemingen voor de wisselkoers-verwachting om ex-ante marktwerwachtingen en risicopremies te meten, heb ik getracht het relatieve belang van beide verklaringen te kunnen duiden. De belangrijkste conclusie die uit zowel mijn onderzoek als andere panel-data studies naar voren komt is dat voor dollarkoersen de voorspelfouten voornamelijk toe te schrijven zijn aan irtationele verwachtingen, terwijl voor wisselkoersen bimnen het Europees Monetair Stelsel (EMS) risicopremies de belangrijkste rol speelden. ${ }^{5}$ Blijkbaar is het karakter van de door velen geconstateerde systematische voorspelfouten (deels) afhankelijk van het onderhavige regime van vaste of zwevende wisselkoersen.

Is het nu mogelijk deze schijnbare controverse tussen theorie en prakts

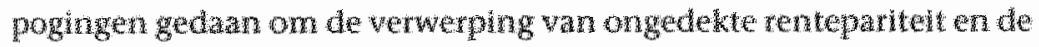

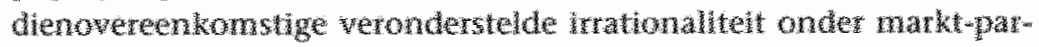

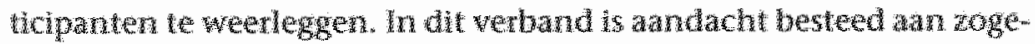

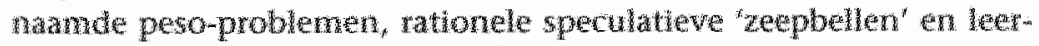

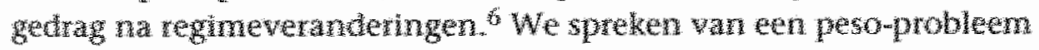
wameer een grote schok wel is gemcampread in de verwachtingen 
van marktparticipanten, maar zich niet als zodanig manifesteert binnen de steekproef, zodat deze niet representatief is. Bit rationele zeepbellen zijn beleggers in het algemeen op de hoogte van het feit dat de wisselkoers afwijkt van de evenwichtskoers. Ze wegen daarbij echter het verlies dat ze lijden als de koers terugvalt tot de evenwichtskoers af tegen de winst die ze maken als de koers nog een tijdje blijft stijgen.

Onze ervaringen met vaste wisselkoerssystemen laten zien dat het peso-probleem een alternatieve verklaring kan bieden voor de ex-post geconstateerde systematische voorspelfouten gedurende korte perioden die consistent is met de efficiente markthypothese. Het is echter niet waarschijnlijk dat dit voor zwevende wisselkoersen het geval is. Ook de atternatieve mogelijkheden, zoals leergedrag en rationele zeepbellen hebben tot dusver (te) weinig opgeleverd en zijn moeilijk van elkaar te onderscheiden. Als belangrijkste oorzaak hiervoor geldt het ontbreken van een adequat macro-economisch model dat inzicht geeft in "de" evenwichtswisselkoers en als zodanig een leidraad bledt voor de verwachtingen. ${ }^{7}$

Het is evident dat, gezien de centrale rol die toekomstverwachtingen innemen bij het verklaren van wisselkoersbewegingen, verder onderzoek naar het peso-probleem en heterogeniteit van verwachtingsvormen perspectief biedt op meer inzicht in ditt terrein van de internationale financiering. Te meer, daar een juiste interpretatie van onze verwachtingen omtrent de toekomst sterk wordt beïnvloed door extreme prijsschommelingen op financielle markten die veelal het gevolg zijn van een internationale wertrouwensbreuk. De recente financiële en morele crises in Azië, Latijns Amerika en Rusland illustreren dit; bescherming van de mondiale financiële stabiliteit vereist derhalve een versterking van de internationale financiële architectuur en het dienovereen komstige inzicht in de risico's van globalisering. In dit kader bezlen is het van belang dat de discussie zich niet zal beperken tot vragen over de relevantie van het peso-probleem in tijden van financlele crises; ook de mate waarin dergelijke crises door marktparticipanten worden geanticipeerd, op welke wijze de besmetting platsheeft en de veronderstelde samenklontering moeten worden onderzocht. Hier ligt een uitdlaging voor de financieel-econoom, een uitdaging die ook ik will aangaan. 


\section{DE PUZZEL VAN DE RISICOPREMIE}

Veronderstel dat uw grootmoeder in 1930 het nobele plan had opgevat om voor haar toekomstige kleinkinderen, als appeltje woor de dorst, EUR 452,49 (1.000 gulden) te investeren. Gezien de turbulente ontwikkelingen rondom de aandelencrash van 1929 besloot ze al haar beschikbare geld te investeren in een risicovrije belegging in schatkistpapier. Gedurende de investeringsperiode 1930-2000 was het gemid. delde rendement op deze belegging $3,7 \%$, waatbij de door uw grootmoeder ingelegde gelden accumuleerden naar een eindwaarde van EUR $5.755,66$ (12.720 gulden). Dit terwijl het gemiddelde rendement op een gespreid aandelenfonds in dezelfde periode ruim $10 \%$ bedroeg en de eindwaarde zelfs EUR $380.995,48$ (842.000 gulden), oftewel ruim 66 maal zoveel. Het ex-ante verschil tussen de rendementen van beide soorten van belegging noemen we de risicopremie op aandelen ondat wordt aangenomen dat beleggers een premie verlangen als vergoeding voor het gelopen risico op aandelen. Naarmate beleggers meer risico-avers zijn, zal de risicopremie op aandelen hoger zijn. Tot zover lijkt alles dus in orde, echter de schijn bedriegt ook hier. Omvangrijk empirisch onderzoek heeft aangetoond dat over een periode van meer dan 100 jaar, deze risicopremie zo hoog is dat dit duidt op een onrealistische waarde voor de risico-aversie van beleggers. ${ }^{8}$ Deze bevimding werd voor het eerst naar voren gebracht door een onderzoek van Mehra en Prescott (1985) voor de Verenigde Staten (VS). In de periode 1889-1978 was het gemiddelde reële rendement op aandelen volgens de Standard $\&$ Poor-index bijna $7 \%$. Een risicovrije belegging, daarentegen, leverde in dit tijdvak reëel nog geen $1 \%$ per jaar op. Het verschil is een risicopremie van bijna $6 \%$, hetgeen aanmerkelijk hoger is dan werd verwacht op grond van de algemene evenwichtstheorie van het beleggingsgedrag. ${ }^{9}$ De risicopremie is dermate hoog dat deze alleen bij zeer onrealistische waarden voor risico-aversie van beleggers kan worden verklaard. We kunnen derhalve constateren dat de empirische bevindingen ook her een algemeen aanvard wetenschappelijk paradigma ernstig in twijfel trekken. De achterliggende hypothesen in het model gaan wederom uit van een over de tijd naar nutsmaximalisatie strevende en rationeel handelende consu- 
ment, warin het beleggingsgedrag wordt bepaald door de mate (van samenhang) van risico-aversie en de tijdsvoorkeur (het geduld) van de consument. De risicopremie hangt positief samen met de mate van risico-aversie wan de belegger: bij risicomijdend gedrag is men bereid te betalen woor een groot risico met een geringe kans (bijwoorbeeld het afsluiten van een branderzekering) terwijl bil risicozoekend gedrag men wil betalen bij een kleine kans op een grote winst, zoalls meedoen aan een loterif, investeren in dot.com bedrijven en aanverwante illusies.

Gezien de relevantie van de aandelenrisicopremie ten aanzien van het voorspellen van toekomstige rendementen, de bepaling van de vermogenskostenvoet en de dienovereenkomstige waardering van bedrijven zijn er het afgelopen decennium vele pogingen ondernomen om deze anomalie te verklaren. De eerste lijn is de theoretische, die probeert door verfijning of relativering van de gebruikte veronderstellingen de robuustheid van de conclusie op de proef te stellen. Bijvoorbeeld door het feit dat beleggers een kleine kans op cen grote schok in de economie verwachten, maar dat deze zich (nog) niet daadwerkelijk heeft gemanifesteerd in de steekproef. ${ }^{10}$ Als de schok dan uitblijft, lijkt het alsof beleggers onwaarschijnlijk risico-avers zijn, terwijl zij slechts de verwachte schok incorporeren in hun prijsvormingsproces. De tweede aanvalslijn is empirisch van aard en richt zich met name op een uitbreiding van de door Mehra en Prescott gebruikte gegevens voor de VS. De meest omvangrijke studie betreft het recente onderzoek van Dimson, Marsh en Staunton (2002) die een aanzienlijke ruimere steekproef van vijftien geindustrialiseerde landen in de beschouwing betrekt. Over een zeer lange termijn bezien, vertoont de aandelenrisicopremie in deze landen een overeenkomstig patroon, met een gemiddelde aandelenpremie van ruim 5\%. Dit werpt meteen de vraag op: hoe is het mogelijk dat de hoogte van deze premie persistent is met het verstrijken der jaren? Warrom is bijvoorbeeld de belangstelling woor het beleggen in andelen niet gestegen tot een dusdanig niveau waarbij - als gevolg van de toegenomen vraag naar aandelen - de koersen verder stijgen en het geěiste lange termijn rendement op aandelen dienovereenkomstig zal dalen - met alle negatieve gevolgen voor de risicopremie van dien. In dit licht bezien, kun- 
nen we constateren dat de anomalie van de aandelenpremie, de overvloedig nadere analyses ten spijt, nog steeds een puzzel is.

\section{DE PUZZEL VAN DE BETA}

Zoals eerder gesteld, blijken er ook in de beleggerspraktijk diverse rendementswerhoudingen te bestaan, die in strijd zijn met thet bestaan van marktefficiëntie. Hierdoor zouden zich mogelijkheden kunnen voordoen om risicoloze "excess"-rendementen te behalen. Belangrijk in dit verband is het feit dat sinds het begin van de jaren ' 80 de onder. steuning van het CAPM terugviel vanwege de ontdekking wan een aantal anomalieën. In grote lijnen komt het erop neer, dat bepaalde eigenschappen van bedrijwen - naast de beta van het CAPM - verklaringskracht hebben ten aanzien van het verwachte rendement van het aandeel in kwestie. Twee van de meest aansprekende, en controversiële verschijnselen op dit gebied zijn het zogenaamde size effect en walue effect. Het eerste verschijnsel refereert aan het feit dat aandelen van relatief kleine bedrijven een gemiddeld hoger rendement behalen dan volgens de efficiènte marktportefeulle efficiënt het geval zall zijn; het andere effect houd" in, dat een aandeel met een relatief hoge boekwaarde van het eigen vermogen ten opzichte van de marktwaarde van het eigen vermogen - zogenaamde value stocks - een hoger rendement zal behalen dan de efficiènte marktportefeuille woorschrifft. Beide effecten worden gevonden na correctie van het systematische deel van het risico van de belegging, dus na rekening te houden met de beta van het aandeel ten opzichte van de marktportefeuille.

Bovenstaande anomalieën zijn getoetst voor een grote diversiteit aan landen en tijdsperioden. ${ }^{11}$ Ook in methodologisch opzicht verschillen de onderzoeken van elkar. Terwijl de ondersteuning vanuit de modellen minimal te noemen is, is het bewijs van de empirische relewantie van deze twee effecten zeer omvangrifk; het standaard CAPM is niet geheel in overeenstemming met de economische realiteit. Een logische kandidaat woor de verklaring van deze anomalieen is dat deze het resultat zouden kunnen zijn van data-minimg of een survivorship bias. Een surviworship bias kan bijvoorbeeld ontstaan doordat 
de data van failliete bedrijven niet meer worden meegenomen in thet onderzoek. Het is waarschijnlijk dat van de kleine bedrijven een relatief groter gedeelte failliet is gegaan dan van de grote bedrijven. Indien nu enkel de succesvolle bedrijen in een onderzoek worden meegenomen, dan bestaat de kans dat kleine bedrijven gemiddeld beter presteren, zelfs wanneer de marktportefeuille in werkelijkheid wel efficiènt is.

Afgelopen decennia zijn er meerdere afwijkingen van het CAPM gedocumenteerd die er alle op wijzen dat de marktportefeuille niet efficiènt is; beleggers maken op een verschillende manier hun risico en rendementsafwegingen in hun beleggingsbeslissing. Dit heeft aanleiding gegeven tot zogenaamde multi-beta modellen, waarin verwachte rendementen niet alleen afhangen van hun samenhang met het marktrendement maar ook met andere factoren. Met name het vier-factor model van Carhart (1997) lijkt in principe een veelbelovende route; empirisch is het model dan ook zeer succesvol en wordt inmiddels in de beleggerspraktijk toegepast voor bijwoorbeeld het meten van de prestaties van beleggingsfondsen. Een dissonant, echter wordt gevormd door het gebrek aan een goede economische onderbouwing van het model en de gehanteerde risicopremies. Het identificeren van economisch relevante variabelen en allerlei marktbeperkingen, alsmede hun invloed op prijsvormingsmodellen op financiële markten is dan ook eén van de grote uitdagingen op dit gebied.

\section{SCHOTEN VOOR DE BOEG}

Opvallend is nu, dat met name de financiële theorie heeft laten zien dat mensen van vlees en bloed zich niet gemakkelijk in de mal van homo economicus laten persen; de financiële markten werken dus niet altijd zo perfect als wel wordt aangenomen. Dit beeld wordt versterkt door de eerder besproken anomalieèn; ondanks een aantal alternatieve verklaringen zijn we tot op heden niet in staat om de schijnbare tegenstellingen adequat te kunnen weerleggen. Enkel de veronderstelling dat op zijn minst sommige marktparticipanten hun verwachtingen op een irrationele wijze vormen biedt hier uitkomst; een breed spectrum van empirisch onderzoek aan de hand van - disect 
waameembare - rente- en wisselkoersverwachtingen ondersteunt deze gedachtegang. ${ }^{12}$ Essentieel is dus dat de financieringstheorie, die rationaliteit hoog in het vaandel heeft staan, irrationaliteit moet aannemen om het bestaan van de besproken controverses te kunnen verklaren. De gevonden puzzels ondermijnen daamee echter de validiteit van de veronderstelling van rationele verwachtingen als werkhypothese in de neo-klassieke economische theorie, hetgeen verstrekkende consequenties kan hebben voor het heersende wereldbeeld van de econoom.

Een aansprekende rol in deze discussie wordt ingenomen door de ontwikkelingseconoom Amartya Sen die in 1998 de Nobelprijs voor de economie ontving. De kern van Sen's kritiek is dat hil de economische subjecten in de neo-klassieke theorie als rational fools bestempelt. Wat hij hiermee beoogt, wordt duidelijk in de navolgende beschrijving van een ontmoeting tussen twee vreemden: Where is the railway station?, he asks we. There, I say, pointing at the post office, and would you please post this letter for me on the way?, Yes, he says, determined to open the envelope and check whether it contains something valuable. Waar het om gaat in deze karikatuur is dat er in veel situaties sprake is van onvolledige informatie. Partijen in het economisch verkeer zijn bijvoorbeeld onvoldoende op de hoogte van de intenties van de tegenpartij en kunnen niet alle alternatieven overzien; de werkhypothese staat dus wel erg ver af wan het werkelijke gedrag van economische subjecten.

Rationaliteit behoort wellicht niet tot de genetische basisuitrusting van de mens; de mens mag dan voor tachtig procent voldoen aan het neo-klassieke profiel van de rationeel calculerende burger, zijn gedrag blijft voor twintig procent eigenmachtig en in economische termen irrationeel. Zo blijkt bijvoorbeeld dat marktparticipanten in hun beslissingen overwegingen van eerlijkheid en rechtvaardigheid een rol laten spelen. Waarom rennen mensen een ander huis binnen om een ander te redden? Waarom zijn ze bereid te sterven voor een beginsel? Ook zijn er drijfveren die door sommige beleggers wel, maar door andere niet als rationeel of zelfs maar als begrijpelijk worden. geaccepteerd. De wens om 'groen' te beleggen bijvoorbeeld of het besluit af te zien van beleggingen in een bepaald land of bedrijf om politieke of ideologische redenen. Teit is nu dat die ontbrekende twin- 
thg procent, waar nutsmaximalisatie moet wijken voor de meer tijdloze passies als trots, schaumte, rechtvaardigheid en verontwaardiging, het domein van onze cultuur en politiek is en zij heeft als zodanig twee gezichten; naast een flinke dosis altruisme worden beleggers en managers soms ook gedreven door dezelfde almachtsfantasieèn als Romeinse consuls of middeleeuwse vorsten. Het behoeft mijns inziens dan ook geen verder betoog dat de recente financiële malversaties van bedrijwen als Lnron en World,com aan dergelijke motieven kunnen worden toegeschreven.

Francis Fukuyama stelt in zijn in 1995 gepubliceerde boek Trust: The Social Virtues and the Creation of Prosperity, dat zonder het samenspel van deze irrationele driffveren de vrije markt niet eens zou kunnen functioneren. Alle handelingen wan de homo economicus zijn zinloos als ze niet zijn ingebed in een dominant ethos, dat wortelt in de cultuur. De empirische rellevantie wan gedrag dat niet uitsluitend is gebaseerd op het najagen van het eigenbelang, maar waarbij ook ruimte is ingebouwd woor tijdloze beguippen als sympathy, commitment en self-command, krijgt in dit licht extra betekenis. Met een reuzenzwaai van honderdtachtig graden draait de neo-klassieke economie om haar as en wordt ze met beide benen op de grond gezet; niet de marktwerking bepaalt de cultutr, maar de traditionele cultuur van een land bepaalt hoe de markt er functioneert, met alle gevolgen van dien.

\section{KOERSBERICHT}

Hoe kijken we nu binnen het domein van de internationale financiering aan tegen al deze anomalieën en wat zijn daarbij onze mogelijkheden? In principe kunnen we twee ontsnappingsroutes volgen. Allereerst hebben we de mogelijkheid de huidige theorie verder uit te bouwen en te verfijnen tot de tot dan toe onbegrepen verschijnselen erin kumnen worden ondergebracht. Volgens het gebruikelijke patroon van de ontwikkeling van wetenschappelijke kennis gaan we naarstig op zoek naar ontbrekende stukjes van de legpuzzel om bijvoorbeeld het gedrag van wisselkoersen beter te kunnen voorspellen, of om in de toekomst beter te kunnen inspelen op internationale 
financiële crises en het aanverwante besmettingsgevaar uit andere landen. Essentieel is dus dat de anomalieën als zodanig een bron van inspiratie voor verder onderzoek vormen; ik hoop dan ook zelf actief betrokken te blijven bij deze uitdagende richting van onderzoek. Naast mogelijke maatschappelijke toepassingen, verwacht ik dat mijn onderzoek voomamelijk zal leiden tot meer kennis van het (heterogene) gedrag van marktparticipanten tijdens perioden van financiejle, en soms ook morele turbulentie. Dit opent wellicht de weg naar een beter begrip van het functioneren van de mondiale kapitaalmarkten en de onderliggende mechanismen van internationale financièle (in)stabiliteit.

Meer fundamenteel bezien, kunnen de anomalieèn de hele zaak op zijn kop zetten. Dat is het geval wanneer de bestaande theorie niet kan worden aangevuld of verfijnd; deze moet dan noodgedwongen worden verworpen. Het pure streven nar eigenbelang door rationeel handelende individuen op perfect werkende markten, enzovoorts het klopt allemaal niet meer. Wat overbijft is dat het wereldbeeld van de econoom tegen de grenzen van zijn eigen veronderstellingen oploopt en uiteindelijk zit opgezadeld met slechts een lege huls. Het heeft er dus alle schijn van dat we aan de vooravond staan van belang. rijke veranderingen in het ecomomisch denken. In dit licht krijgt het gedachtengoed van Sen en Fukuyama extra betekenis; beiden zien dat het sociaal kapitaal van de economie in het stelsel van normen en waarden verankerd ligt. In dat geval rest ons niet anders dan op zoek te gaan naar nieuwe paradigma's of aan te klampen bij aanverwante wetenschappen, zoals de psychologie en de sociologie. Dit inzicht leidt ons naar een theorie van begrensd rationeel gedrag waarin biologische en cognitieve beperkingen aan menselijk gedrag worden opgenomen. De contouren hiervan zijn reeds zichtbaar in het vakgebied 'Behavioral Finance, ' waarbij gedragswetenschappelijke aspecten een centrale rol spelen. Ook binnen ons Departement Financiering wordt in toenemende mate aandacht besteed aan de mogelijke invloed van systematische irrationaliteit op de prijsvorming van vermogenstitels. Illustratief hiervoor is het onlangs op dit gebled georganiseerde congres door - een gezamenlijke inspanning van - het Journal of Empiricat Finance en het Limburg Institute of Financial Economics (LIFE). Over 
de toekomst valt momentee nog niet veel te zeggen behalve dan dat het perspectief goed is. De tijd echter zalleren waar de grenzen liggen, voordat het granieten paradigma van optimale keuzes door rationele mensen wordt verlaten en de economie dientengevolge zal binnentreden in een nieuw wetenschappelijk denken.

\section{DANKWOORD}

Mijnheer de Rector Magnificus,

Dames en heren,

IK wil deze inaugurele rede eindigen met een woord van dank aan degenen die hebben bijgedragen aan mij benoeming als hoogleraar Internationale financiering. I $k$ voel mij zeer bevoorrecht dat ik aan deze jonge en dynamische universiteit de kans heb gekregen mijn persoonlijke ambities te verwezenlijken. Ilk stel het daarom op prijs het College van Bestuur, het Bestuur van de Faculteit der Economische Wetenschappen en Bedrijfskunde en de Stichting Wetenschapsbeoefening Universiteit Maastricht te danken voor het in mij gestelde vertrouwen.

Leden van het Departement Financiering,

Ik heb reeds betoogd dat wetenschap mensenwerk is. Het onderling vertrouwen en de karakteristieke wetenschappelijke ambiance binnen ons Departement hebben mij in de afgelopen jaren geïnspireerd, waarvoor ik jullie dank wil zeggen. Ik ben er trots op dat we de goede sfeer in al die jaren hebben weten om te zetten in prestaties die in brede kring worden gewaardeerd. De recente uitkomsten van de onderzoeksvisitaties Economie en Bedrijfskunde in Nederland tonen aan dat wij al ruim een decennium tot de Europese onderzoekstop behoren. Dat betekent dat er hoge eisen worden gestell aan de verantwoordelijkheid van alle leden van het Departement, en ik hoop dit - samen met jullie - war te maken.

Hooggeleerde Wolff, beste Christian, Als geen ander ben jij verantwoordelijk voor mijn wetenschappelijke 
vorming. De aantrekkingskracht van jouw opleiding, onderzoek en persoonlijkheid, heeft mij destijds doen besluiten als promovendus naar Maastricht te gaan. In de jaren die volgden, ben ik onder de indruk geraakt van jouw stijl als wetenschappelijk leider en de bijzondere wijze waarop jij mij en vele anderen hebt weten te inspireren. Onze langdurige samenwerking heeft ook onze persoonlijke band. hecht gemaakt. Ik dank je voor het vele dat ik van je heb geleerd en voor al je steun en vriendschap.

\section{Weledelgestrenge Lugard, beste Paul,}

Ook jou wil ik hier noemen. Onze eerste ontmoeting dateert van een ver verleden, ergens begin jaren ' 80 op het Groningse platteland tijdens een imitatie van een van jouw meest favoriete zangers - Lou Reed. Nadien hebben we samen in het studentenhuis, Westersingel 23 , gewoond en daar vele moole momenten beleefd. Tijdens die jaren heb jij mij weten te stimuleren en mijn - destijds latente - belangstelling voor de wetenschap geïntensiveerd. Nog belangrijker, echter, is het feit dat jij toen een jonge, beeldschone gymnasiaste aan ons huis en wat later aan mij - hebt toevertrouwd. Ik wil je voor al die bijzondere jaren en de betoonde vriendschap dankzeggen.

\section{Lieve mama en papa,}

Ik beschouw het als een voorrecht on samen met jullie deze dag te mogen beleven. Graag wil ik jullie danken voor de onvoorwaardelijke steun die ik in al die jaren heb ontvangen, zowel in emotionele als financiële zin. Dit laatste blijkt ook uit het feit dat "thuisbankieren" bij ons 25 jaar geleden al gemeengoed was, zelfs lang voordat de Postbark dit concept op de markt introduceerde.

\section{Lieve Lieke,}

I $\mathrm{k}$ vind het heel bijzonder dat ik je in de aula van de voormalige Rechtbank Maastricht kan toespreken. Dit karakteristieke gebouw staat symbool voor die mooie tijd in Maastricht en het begin van een indrukwekkende loopbaan bij de Rechterlijke Macht. Naast al je professionele bezigheden en de zorg voor onze kinderen ben jij ook degene die deze 
dag mogelijk heeft gemaakt. Zonder jou was ik niet waar ik nu ben. Ik ben je hiervoor iedere dag weer dankbaar.

Lieve Floris en Sophie, Jullie zijn mijn favoriete anomalie. Jullie gaan rechtsaf de bocht om als het volgens mijn theorie links moet zijn, kijken televisie als je wordt geacht al lang en breed in bed te liggen, eten met je handen als het soms zilveren - bestek binnen handbereik ligt, enzovoorts. Voor jullie zit de wereld nog exact en logisch in elkaar, terwijl wij 'volwassenen' deze gedachte helaas hebben losgelaten. I $\mathrm{k}$ zal daarentegen proberen jullie overtuiging zo lang mogelijk te blijven koesteren.

Ik dank $u$ allen voor uw zeer gewaardeerde aandacht.

Ik heb gezegd. 


\section{REFERENTIES}

Brouwer, A, 1995, De reuzenzwalai, De Groene Amsterdammer.

Carhart, M.M., 1997., On Persistence in Mutual Fund Performance, fournal of Finance, 52: 57-82.

Cavaglia, S., W.F.C. Verschoor and C.C.P. Wolff, Further Evidence on Exchange Rate Expectations, Journal of International Money and Finance, 12: 78-98.

Cavaglia, S., W.F.C. Verschoor and C.C.P. Wolff, 1994, On the Biasedness of the Forward Foreign Exchange Rates: Irrationality or Risk Premia, Fournal of Business, 67: 321-343.

Coase, R.H., 1988, The Firm, the Market and the Law, University of Chicago Press, Chicago.

Dimson, E.,P. Marsh and M. Staunton, 2002, Triumph of the Optimists: 101 Years of Global Investments Returns, Princeton University Press, Princeton, USA.

Fama, E. and $K$. French, Value versus Growth: The International Evidence, Journal of Finance, 53: 1975-1999.

Fase, M.M.G. en W.F.J. van de Poll, 1996, De risicopremie op aandelen: een puzzel?, Economisch Statistische Berichten, $1014-1017$.

Feinman, J.N., 2001, The Equity Premium, Deutsche Asset Management, Global Outlook.

Frankel, J.A. and K.A. Froot, 1987, Using Survey Data to Test Propositions Regarding Exchange Rate Expectations, American Economic Review, 5: 133-153.

Frankfurther, G.M. and E.G. McGoun, 2001, Anomalies in Finance: What are they and what are they good for?, International Review of Financial Analysis, 10:407-429.

Froot, K.A. and J.A. Frankel, 1989, Forward Discount Bias: Is it an Exchange Risk Premium?, Quarterly Joumal of Economics, 139-61.

Froot, K.A. and R.H. Thaler, 1990, Anomalies: Foreign Exchange, foumal of Economic Perspectives, 3: 179-192.

Geest, van der, L., 1995, Zwarte gaten, Economisch Statistische Berichten, 217. 
Fukuyama $F_{n}, 1995$, Trust: The Social Virtues and the Creation of Prosperity, Hamish Hamilton.

Groot, De, C.A. and W.F.C. Verschoor, 2002, Further Evidence on Asian Stock Return Behavior, Emerging Markets Review, 3: 179-193. Hooykaas, R., 1972, Geschiedenis der Natuurwetenschappen, Bohn, Scheltema, Holkema.

Jongen, R, 2002, Foreign Exchange Market Survey Studies: A Record of Empinical Research since the 1980s, Masters Thesis, Maastricht University.

Icke, V., 2001, Passie en precisie, NRC-Handelsblad.

Kool, C.J.M., 1995, Koffiedik kijken op de valutamarkt, Economisch Statistische Berichten, 232-235.

Krasker W.S., 1980, The Peso Problem in Testing the Efficiency of Forward Exchange, Joumal of Monetary economics, 6: 269-276.

Kuhn, T.S., 1970, The Structure of Scientific Revolutions, Chicago: The University of Chicago Press.

Lucas, R.E., 1978, Asset Prices in an Exchange Economy, Eonometrica, $1429-1445$.

Markowitz, H., 1952, Portfolio Selection, Joumal of Finance, 7: 77-91. Mehra R. and E.C. Prescott, 1985, The Equity Premium: A Puzzle, Joumal of Monetary Economics, 15: 145-161.

Robbins, L., 1932, An essay on the Nature and Significance of Economic Science.

Rubinstein, M., 2001, Rational Markets: Yes or No? The Affirmative Case, Financial Analyst Journal.

Siegel, J.J. and R. H. Thaler, 1997, Anomalies: The Equity Premium Puzzle, Jotumal of Economic Perspectives, 11: 191.-2000.

Verschoor, W.F.C., 1994, Voorspelfouten van EMS termijnkoersen: irrationaliteit of risicopremies?, VBA joumaal, $2: 14-20$. 


\section{NOTEN}

1 Als werkhypothese wordt in de traditionele neo-klassieke theorie een economisch subject gebruikt dat volledige kennis heeft van alle omstandigheden die zijn keuzes beinvloeden alsmede volkomen kennis van de toekomst (perfect foresight). Het subject is derhalve in staat alle alternatieven tegen elkaar af te wegen, waarbij het een logisch consistent gedrag vertoont: als het $A$ meer waardeert dan $B$ en $B$ meer dan $C$ dan waardeert het $A$ meer dan C.

2 Zie R.H. Caase(1988).

3 De hypothese van rationele verwachtingen veronderstelt dat elk individu het onderliggende economisch model kent en dat systematische voorspelfouten uitgesloten zijp.

4 In geval van ongedekte rentepariteit en rationele verwachtingen is de termijnkoers gelijk aan de verwachte toekomstige contante koers; de verwachte speculatie-opbrengst is dan gelijk aan nul.

5 Zie bijwoorbeeld S. Cavaglia, W.F.C. Verschoor en C.C.P. Wolff, (1993, 1994), J.A. Frankel en K.A. Froot, (1987) en K.A. Froot en J.A. Frankel (1989). De in de tijd warièrende risicopremies kunnen we interpreteren als een premie voor latente verwachtingen van toekomstige depreciaties van EMS-wisselkoersen.

6 Zie bijwoorbeeld K.Lewis, (1989a, 1989b) en W.S. Krasker, (1980).

7 Zie bijvoorbeeld R.P. Food en R.J. Hodrick, (1990).

8 Zie J.N. Feinman (2001), M.M.G. Fase en W.F.J. van de Poll (1996) en J.J. Siegel en R.H. Thaler (1997).

9 Bedoeld wordt hier het consumptie-georiennteerde vermogensprijsvormingsmodel, ofwel het Consumption Capital Asset Pricing Model (CCAPM); zie bijvoorbeeld Lucas (1978).

10 In feite is dit een variant van het "peso-probleem"; zie W.S. Krasker (1980).

11 Zie bijvoorbeeld $\mathbb{E} . F$. Fama en K.R. French (1998) en C.A. De Groot en W.F.C. Verschoor (2002).

12 Zie bijvoorbeeld Cavaglia, Verschoor en Wolff (1994) en R. Jongen, (2002). 